\title{
PENGARUH EKSTRAK BUAH MENGKUDU (MORINDA CITRIFOLIA) TERHADAP PERTUMBUHAN STAPHYLOCOCCUS AUREUS The Effect of Noni Fruit Extracts (Morinda Citrifolia) on Staphylococcus aureus growth
}

\author{
${ }^{(1)}$ RISNAYANTI R. DJURAMANG \\ Fakultas Keguruan dan Ilmu Pendidikan Univ. Muhammadiyah Luwuk \\ email: Dj.Risnayanti@gmail.com \\ ${ }^{(2)}$ YULIANA RETNOWATI \\ (3) NURHAYATI BIALANGI
}

\begin{abstract}
This aim of study was to determine the effect of noni fruit extract on Staphylococcus aureus growth. Indicator is the Bacteria growth of diameter inhibitory zone formed. The study was conducted at the Laboratory of Microbiology, Departement of Biology, State University of Gorontalo. The research method was experimental which consisted of 12 treatments $(15 \%, 10 \%, 15 \%, 20 \%, 25 \%, 30 \%, 35 \%, 40 \%, 45 \%, 50 \%)$ and 2 replicates, and quantitatively analyzed using non-parametric Kruskal Wallis Test. Based on the statistical results indicate that there is influence of noni fruit extract on the growth of Staphylococcus aureus at 15\%,10\%, 15\%, 20\%, 25\%, 30\%, 35\%, 40\%, 45\%, and 50\% concentrations, with a diameter of inhibition zone formed by each is $7,87 \mathrm{~mm}, 7,75 \mathrm{~mm}$, $8,81 \mathrm{~mm}, 9,62 \mathrm{~mm}, 9 \mathrm{~mm}, 10,44 \mathrm{~mm}, 10,88 \mathrm{~mm}, 12 \mathrm{~mm}, 8,37 \mathrm{~mm}$ and $12,13 \mathrm{~mm}$. This result is evidenced by the Kruskal Wallis $000 \leq 0,05$.
\end{abstract}

Keyword: Growth, Staphylococcus aureus, Extraction, Noni, Inhibitory zones.

\section{A. PENDAHULUAN}

Bakteri termasuk mikroorganisme yang dapat menyebabkan penyakit pada manusia, hewan, maupun tumbuhan. Selain itu bakteri juga dapat menyebabkan keracunan pada makanan, sehingga menimbulkan perubahanperubahan kimiawi dan membuat makanan tersebut tidak layak dikonsumsi, yang disebabkan karena kemampuan bakteri tersebut dalam menghasilkan toksin. Salah satunya adalah Staphylococcus aureus, yang merupakan bakteri penyebab keracunan makanan melalui produksi enteroktosin pada makanan yang mengandung karbohidrat dan protein misalnya, susu dan telur (Adelberg dkk, 1996).

Melihat dampak patogen bagi kesehatan manusia, maka perlu dilakukan suatu pengendalian pertumbuhan mikroorganisme tersebut.

Antimikroba adalah suatu obat pembasmi mikroba, khususnya mikroba yang merugikan manusia. Senyawa antimikroba ini dapat menghambat pertumbuhan mikroorganisme, yaitu 
menghambat sintesis dinding sel, merusak membran plasma, menghambat sintesis protein, menghambat sintesis asam nukleat, dan menghambat metabolit esensial.

Dewasa ini telah ditemukan beberapa jenis tumbuhan yang bermanfaat bagi kesehatan dan dapat dimanfaatkan sebagai antimikroba/antibakteri yang alami tanpa menimbulkan efek samping. Salah satu tanaman yang berkhasiat sebagai antibakteri adalah Mengkudu (Morinda Citrifolia) yang merupakan salah satu tumbuhan berkhasiat bagi kesehatan.

Menurut (Adrianto R, 2009) bahwa buah mengkudu mengandung senyawa terpenoid, flavonoid, dan alkaloid. Hal ini dapat memungkinkan mengkudu sebagai salah satu tanaman yang dimanfaatkan sebagai sumber senyawa antimikroba.

\section{RUMUSAN MASALAH}

Berdasarkan latar belakang di atas, maka yang menjadi permasalahan pada penelitian ini adalah "apakah terdapat pengaruh ekstrak buah mengkudu (Morinda citrifolia) terhadap pertumbuhan Staphylococcus aureus".

\section{B. METODE PENELITIAN}

Penelitian ini dilaksanakan dilaboratorium Mikrobiologi Jurusan Biologi Fakultas MIPA Universitas Negeri Gorontalo, selama 3 bulan.
Desain penelitian yang digunakan adalah Rancangan Acak Lengkap (RAL) yaitu 12 perlakuan 2 ulangan. Metode penelitian yang digunakan adalah eksperimen dengan analisis statistik kuantitatif, yang menggambarkan pengaruh ekstrak etanol buah mengkudu terhadap pertumbuhan $S$. aureus. Menggunakan 12 perlakuan yaitu :

Perlakuan A : Ekstrak etanol buah mengkudu dengan konsentrasi $5 \%$.

Perlakuan B : Ekstrak etanol buah mengkudu dengan konsentrasi $10 \%$.

Perlakuan C : Ekstrak etanol buah mengkudu dengan konsentrasi $15 \%$.

Perlakuan D : Ekstrak etanol buah mengkudu dengan konsentrasi $20 \%$.

Perlakuan E : Ekstrak etanol buah mengkudu dengan konsentrasi $25 \%$.

Perlakuan F : Ekstrak etanol buah mengkudu dengan konsentrasi $30 \%$.

Perlakuan G : Ekstrak etanol buah mengkudu dengan konsentrasi $35 \%$.

Perlakuan $\mathrm{H}$ : Ekstrak etanol buah mengkudu dengan konsentrasi $40 \%$. 
Perlakuan I : Ekstrak etanol buah mengkudu dengan konsentrasi $45 \%$.

Perlakuan J : Ekstrak etanol buah mengkudu dengan konsentrasi $50 \%$.

Kontrol (-) : Aquades (tanpa ekstrak etanol buah mengkudu).

Kontrol (+) : Amphicilin.

Prosedur dalam penelitian ini terdiri dari 6 tahapan, yaitu : 1) Menyiapkan alat dan bahan penelitian. 2) Sterilisasi Alat, alat-alat yang digunakan harus dalam keadaan steril, dengan terlebih dahulu dicuci sampai bersih kemudian dikeringkan. 3) Pembuatan ekstrak etanol buah mengkudu, buah mengkudu dihancurkan dengan cara diblender, lalu disaring untuk proses ekstraksi dengan cara maserasi menggunakan pelarut etanol. Ekstrak direndam ke dalam larutan etanol selama 3 x 24 jam, setiap 24 jam ekstrak disaring dan diganti dengan larutan etanol yang baru, kemudian saringan dari hari ke-1 s/d ke-3 disatukan dan dipekatkan dengan menggunakan evaporator (pada suhu 30$40^{\circ} \mathrm{C}$ ) sampai diperoleh ekstrak kental etanol. 4) Pembuatan medium NA (Nutrient agar) dan NB (Nutrient broth), membuat NA dengan melarutkan 4,2 gr NA kedalam $150 \mathrm{ml}$ aquades steril, lalu dipanaskan di atas kompor listrik selama
10-15 menit, kemudian disterilkan dalam autoclave pada suhu $121^{\circ} \mathrm{C}$ selama 15 menit. Membuat NB dengan melarutkan 0,4 gr NB dalam $50 \mathrm{ml}$ aquades steril, lalu dipanaskan dalam kompor listrik selama 10-15 menit dan disterilakan dalam autoclave pada suhu $121^{\circ} \mathrm{C}$ selama 15 menit. (Hadioetomo dan Ratna S, 1993). 5) Pembuatan starter S. aureus, sebanyak 2 ose kultur murni $S$. aureus ditumbuhkan dalam $50 \mathrm{ml}$ Nutrient Broth steril dan diinkubasi selama 24 jam. 6) Uji daya hambat (Paper disk), uji daya hambat buah mengkudu terhadap pertumbuhan S. aureus didasarkan pada metode difusi cakram (Norel, 1996 dalam Toonawu, 2008). Ekstrak dibuat dalam variasi konsentrasi 5\%, 10\%, 15\%, 20\%, 25\%, $30 \%, 35 \%, 40 \%, 45 \%$, dan $50 \%$, dengan kontrol (-) tanpa ekstrak, dan kontrol (+) amphicilin. Kemudian $1 \mathrm{ml}$ starter diinokulasi secara pour plate pada media NA sebanyak $15 \mathrm{ml}$, dan dihomogenkan dengan cara memutar. Setelah NA padat letakkan 4 paper disk dari setiap perlakuan yang sudah direndam dalam masing-masing stok konsentrasi ekstrak buah mengkudu di atas permukaan medium NA, media diinkubasi pada suhu $37^{\circ} \mathrm{C}$ selama 24 jam. Kemudian diukur diameter zona hambat yang terbentuk. 


\section{HASIL DAN PEMBAHASAN}

Data hasil penelitian pengaruh ekstrak buah mengkudu terhadap pertumbuhan $\quad S$. aureus disajikan pada Tabel 1 dibawah ini.

Tabel 1. Rata-rata diameter zona hambat yang dibentuk ekstrak buah mengkudu terhadap pertumbuhan $S$. aureus.

\begin{tabular}{|c|c|}
\hline $\begin{array}{l}\text { Konsentrasi } \\
\text { Ekstrak (\%) }\end{array}$ & $\begin{array}{c}\text { Ø Zona } \\
\text { Hambat (mm) }\end{array}$ \\
\hline 5 & 7,87 \\
\hline 10 & 7,75 \\
\hline 15 & 8,81 \\
\hline 20 & 9,62 \\
\hline 25 & 9 \\
\hline 30 & 10,44 \\
\hline 35 & 10,88 \\
\hline 40 & 12 \\
\hline 45 & 8,37 \\
\hline 50 & 12,13 \\
\hline Kontrol (+) & 22,13 \\
\hline Kontrol (-) & 0 \\
\hline
\end{tabular}

disekitar kertas cakram menggambarkan sensivitas antibakteria dari ekstrak buah mengkudu dalam menghambat pertumbuhan $S$. aureus. Semakin meningkat konsentrasi ekstrak buah mengkudu maka semakin besar diameter zona hambat yang terbentuk, kecuali pada beberapa konsentrasi $(10 \%, 25 \%$, dan $45 \%$ ) menunjukkan penurunan diameter zona hambat.
Berdasarkan hasil uji statistika yang dibuktikan dengan nilai Kruskal Wallis $\leq 005$, menunjukkan bahwa pemberian ekstrak buah mengkudu sampai pada konsentrasi 50\% mempengaruhi pertumbuhan S. aureus. Sehingga, S. aureus masih dikatakan bersifat resisten terhadap ekstrak buah mengkudu sampai konsentrasi 50\%.

Pertumbuhan diartikan sebagai pertambahan secara teratur semua komponen di dalam sel hidup (Waluyo, 2004). Pertumbuhan organisme pada suatu lingkungan sangat dipengaruhi oleh berbagai faktor lingkungan, misalnya senyawa antimikroba. Antimikroba ialah obat pembasmi mikroba, khususnya mikroba yang merugikan manusia.

Ekstrak buah mengkudu memiliki senyawa-senyawa yang dapat menghambat pertumbuhan bakteri. Dari hasil penelitian pada konsentrasi 5\% sampai $50 \%$ bersifat resisten artinya bahwa ekstrak buah mengkudu dapat menghambat pertumbuhan $S$. aureus tetapi dalam kategori lemah, dilihat dari kemampuan adaptasi bakteri yang ditunjukkan oleh pembentukan zona hambat dengan diameter $\leq 14 \mathrm{~mm}$. Hal ini disebabkan oleh adanya reaksi suatu senyawa kimia sebagai antibakteri dalam ekstrak buah mengkudu, yaitu : 1) senyawa flavonoid, merupakan senyawa kimia yang bersifat sebagai antinakteri. 
Mekanisme kerjanya dengan mendenaturasi protein sel bakteri dan merusak membran sitoplasma. Menurut (Volk dan Wheeler, 1988 dalam Prajitno A, 2007) menambahkan ba sitoplasma yang dapat menyebabkan bocornya metabolit penting dan menginaktifkan sistem enzim bakteri. Kerusakan ini memungkinkan nukleotida dan asam amino merembes keluar dan mencegah masuknya bahan-bahan aktif ke dalam sel, keadaan ini dapat menyebabkan kematian bakteri. 2) senyawa terpenoid, yaitu senyawa yang bersifat antimikroba. Mekanisme kerjanya merusak dinding sel bakteri, merusak membran sitoplasma dan menghambat kerja enzim dalam sel bakteri (Ajizah, 2004). Sedangkan, 3) senyawa alkaloid, memiliki kemampuan sebagai antibakteri dengan cara mengganggu komponen penyusun peptidoglikan pada sel bakteri sehingga lapisan dinding sel tidak terbentuk secara utuh dan tidak sempurna karena tidak mengandung peptidoglikan dan dinding selnya hanya meliputi membran sel.

Penghambatan ekstrak buah mengkudu terhadap $S$. aureus ditunjukkan dengan terbentuknya diameter zona penghambatan yang berbeda pada tiap konsentrasi. Pada umumnya, diameter zona hambat cenderung meningkat sebanding dengan meningkatnya konsentrasi ekstrak.
Tetapi dalam kajian ini terdapat penurunan daya hambat pada beberapa konsentrasi, yaitu pada konsentrasi $10 \%$, $25 \%$, dan $45 \%$. Hal serupa juga dialami oleh (Elifah E , 2010), dimana diameter zona hambat tidak selalu naik sebanding dengan naiknya konsentrasi antibakteri. Kemungkinan hal ini terjadi karena perbedaan kecepatan difusi senyawa antibakteri pada media agar serta jenis dan konsentrasi senyawa antibakteri yang berbeda juga memberikan diameter zona hambat yang berbeda pada lama waktu tertentu. Hal lain yang menyebabkan ketidakteraturan besar diameter zona hambat pertumbuhan bakteri uji adalah pada waktu pengeringan kertas cakram yang tidak sama. Oleh karena itu, menyebabkan zona hambat pada konsentrasi $10 \%$, $25 \%$, dan $45 \%$ terjadi penurunan. Kertas cakram yang waktu pengeringannya cukup lama, saat diletakkan diatas media pembenihan bakteri maka luas daerah zona hambatnya kecil, zona ini terbentuk dari ekstrak yang terdifusi dari kertas cakram ke media agar. Pada kertas cakram yang waktu pengeringannya hanya sebentar, saat diletakkan diatas media pembenihan bakteri, ekstrak yang masih menempel langsung menyebar disekeliling cakram dan cepat berdifusi ke media agar sehingga membentuk zona hambat yang 
lebih besar (Syarif N dan Panagan T. A, 2009).

\section{PENUTUP}

Berdasarkan hasil dan pembahasan dapat disimpulkan bahwa pemberian ekstrak buah mengkudu dapat mempengaruhi pertumbuhan Staphylococcus aureus pada konsentrasi $5 \%, 10 \%, 15 \%, 20 \%, 25 \%, 30 \%, 35 \%$, $40 \%, 45 \%$, dan 50\%. Hasil ini dibuktikan dengan nilai Kruskal Wallis $.000 \leq 0,05$.

\section{DAFTAR PUSTAKA}

Adelberg, Jawetz dan Melnick, 1996. Mikrobiologi Kedokteran. Jakarta: EGC.

Andrianto R, 2009. Potensi Antibakteri Ekstrak Etanol Buah Mengkudu pada Bakteri salmonella typhi. Fakultas Kedokteran UII. (Diakses 13 mei 2010).

Ajizah A, 2004. Sensivitas Salmonella Typhimurium Terhadap Ekstrak Daun Psidium Guajava $L$. Banjarmasin: Universitas Lambung Mangkurat. (Diakses 3 agustus 2011).

Elifah E, 2010. Uji Antibakteri Fraksi Aktif Ekstrak Metanol Daun Senggani (Melastoma candidum D.Don) Terhadap Escherichia coli dan Bacillus subtilis serta Profil Kromatografi Lapis Tipisnya. Surakarta: FMIPA Universitas Negeri Surakarta. (Diakses 207 juni 2011).

Hadioetomo dan Ratna S, 1993. Mikrobiologi Dasar dalam Praktek (Tekhnik dan Prosedur
Dasar Laboratorium). Jakarta: PT. Gramedia Pustaka Utama.

Prajitno A, 2007. Uji Sensifitas Flavonoid Rumput Laut (Eucheuma Cottoni) Sebagai Bioaktif Alami Terhadap Bakteri Vibrio Harveyi. Fakultas Perikanan, Universitas Brawijaya. (Diakses 15 maret 2011).

Syarif N dan Panagan T A, 2009. Uji Daya Hambat Asap Cair Hasil Pirolisis Kayu Pelawan (Tristania abavata) Terhadap Bakteri Escherichia coli. Sumatera Selatan: Universitas Sriwijaya. (Diakses 20 juli 2011 
